\title{
Science for All? Practical Recommendations on Reaching Underserved Audiences
}

\author{
Christian Humm* and Philipp Schrögel ${ }^{*}$ \\ Department of Science Communication, Institute for Technology Futures, Karlsruhe Institute of Technology (KIT), Karlsruhe, \\ Germany
}

OPEN ACCESS

Edited by:

Thomas Hayden

Stanford University, United States

Reviewed by:

Daniel J. Birmingham, Colorado State University,

United States

Patrick Chandler,

University of Colorado Boulder

United States

*Correspondence:

Christian Humm

christian.humm@kit.edu

Philipp Schrögel

philipp.schroege/@kit.edu

Specialty section:

This article was submitted to

Science and Environmental

Communication

a section of the journal

Frontiers in Communication

Received: 20 August 2019

Accepted: 29 May 2020

Published: 07 July 2020

Citation:

Humm C and Schrögel P (2020)

Science for All? Practical Recommendations on Reaching

Underserved Audiences.

Front. Commun. 5:42.

doi: 10.3389/fcomm.2020.00042
In a world decisively influenced by scientific developments science communication grows ever more important to enable informed decision making and participation of citizens in society and political discourse. However, science communication, being it public talks, or participatory projects, often reaches only certain parts of society. While this problem is increasingly recognized, only some empirical results and practical recommendations on success-factors for promoting diversity and inclusiveness in science communication exist so far. If at all, many projects and reports focus on very specific areas with only a few aggregated and overarching best practices and guidelines. This article contributes to filling this gap and presents a set of practical recommendations on reaching and engaging underserved audiences of science communication activities. The proposed guidelines have been developed from the experiences and empirical evidence from the research and practice project "Science for All" in Germany, and are based on a review of existing guidelines and recommendations. They are corroborated by interviews with practitioners, scientists, and underrepresented groups. The seven recommendations include listening to underserved audiences, reducing the distance, illustrating the relevance of science for daily life, going where the people are, cooperating with stakeholders, and multipliers, as well as the problem of too much openness, and one-time activities. The guidelines are primarily addressed at practitioners in the field of science communication and meant to encourage and support a first step toward more diverse and inclusive science communication. However, they are limited wherever the roots of exclusion lay at the societal and political level and are open for discussion. While inclusive science communication alone cannot fix discrimination and inequality in society, a continuous self-reflection and improvement of the communication of science organizations, including the improvement of inclusion and diversity within the organization themselves, is an important contribution to a more equitable society.

Keywords: science communication, inclusion, exclusion, diversity, guidelines, discrimination, underrepresented audiences, marginalized groups

\section{INTRODUCTION}

The formats of science communication and public engagement have diversified in recent years, now comprising science festivals, pub science events, citizen science, citizen dialogues, and various art, and science projects (Niemann et al., 2017). The audiences, however, are still much less diverse, with various groups in society feeling "disengaged" (Schäfer et al., 2018) and that science is "not for me" (Office of Science Technology Wellcome Trust, 2001). 
Besides some in-depth studies on social inclusiveness in science communication [for example in the UK (Dawson, 2019) there are also a number of research and practice projects often focusing on specific excluded groups (e.g. ethnic minorities or persons with disabilities) or specific topics] [for example climate change, as addressed in the Six American's Project of the Yale Program on Climate Change Communication (Leiserowitz et al., 2009) or health communication (Kreps, 2005)]. While the focus of many of these projects and the corresponding specific societal and political conditions (such as party political polarization of an issue or a value-based conflict) pose a specific set of challenges as well as leverage points for science communication, few details are known in the wider science communication practitioners community about who overall does not participate in science communication, why that is the case and what could be done about it. At the same time, the issue is increasingly being noticed as "one of the most pressing problem[s] in science communication" (Scheufele, 2018, p. 3) by society and politics as well as the science communication community itself.

What is known, is that science communication only reaches certain parts of society. This holds for mediated forms of communication like traditional science-journalism, being it print, online, or through radio, or television (Schäfer et al., 2018). But also non-mediated forms, like public lectures, open days at universities, and even more creative, and entertainmentoriented activities mostly attract an audience that has a high formal education, is already knowledgeable, very interested in science, predominantly white, and is affluent (Borgmann, 2005; Gruber et al., 2010; Bultitude, 2014; Kennedy et al., 2017).

Since different mechanisms come into play for mediated and non-mediated science communication (for example media usage patterns or the details of face-to-face interaction between communicator and audience, a separate analysis for both areas is necessary, although there are likely some intersections). Thus, the following article and the presented guidelines focus only on one of the areas-namely non-mediated forms of sciencecommunication to an external public - while leaving the specific consideration of science journalism for another study. Besides this focus, this article builds on a broad definition of science communication as "all forms of communication focused on scientific knowledge and scientific work, (...), including its production, contents, usage and impact." (Schäfer et al., 2015, p. 13). With this broad understanding, there is a large overlap to the consideration of diversity and inclusion in related academic fields such as the study of STEM education (Tsui, 2007; AllenRamdial and Campbell, 2014), public participation (de Freitas and Martin, 2015), or citizen science (Pandya, 2012). However, the focus here is on external science communication, primarily through science organizations.

Audiences of science communication activities can be excluded by a broad variety of factors-each coming into play in different aspects of communication processes and different intensities. Besides specific material exclusion factors, emotional effects play an important role (Humm et al., 2020). The identified factors can be grouped into three categories, as proposed in a typology developed within the project "Science for All" (Schrögel et al., 2018): First, individual factors (e.g., age, fears, educational background, income, literacy, and spelling skills); second, social factors (e.g., disabilities, ethnic background, gender, regional affiliation); and third, structural conditions (e.g., complexity, location, availability of supporting services at events).

In a world significantly shaped by scientific developments (Dawson, 2019, p. 2), this exclusion of various parts of society is problematic for individual lifestyle-decisions (The Royal Society, 1985 , p. 10) with respect to health and risk-taking, for personal science career choices (Blanton and Ikizer, 2019, p. 155), for democratic decision-making and participation in public debates (Thomas and Durant, 1987, p. 5) as well as for informed public support for science (Thomas and Durant, 1987, p. 3) as a publicly funded undertaking.

Yet, the question remains: what can be done by scientists and organizations to reach those underserved audiences in the first place, learn about their interests and perspectives, provide relevant information, engage in a dialogue and, thus, form a communication relationship? While the concrete solutions are as diverse as the range of exclusion factors, some common principles for more inclusive science communication can be identified.

\section{ASSESSMENT OF EXISTING GUIDELINES AND RECOMMENDATIONS}

We took a holistic perspective and developed a set of practical guidelines as basic recommendations for enabling a more inclusive science communication. They illustrate what can work in reaching out to typically underserved audiences, although proposed measures and approaches alone, of course, do not guarantee immediate success.

The guidelines presented in the following article are built on a review of existing guidelines and recommendations and further corroborated by additional qualitative data from the research and practice project "Science for All"1 in Germany.

The overall foundation is three-fold: first, a review of existing guidelines for science communication with underserved audiences; second, interviews with science communication practitioners and researchers; third, the analysis of focus groups and interviews with three exemplary underserved groups as part of the project "Science for All” (Schrögel et al., 2019).

\section{Review of Guidelines and Recommendations}

The review focuses on reports containing specific practical recommendations on reaching underserved or marginalized populations with science communication. General (policy) statements on the issue without further elaboration, as well as

\footnotetext{
${ }^{1}$ The project "Science for All" ["Wissenschaft für alle"] develops and evaluates science communication formats with underserved audiences. To that end, a typology of exclusion factors has been developed based on a literature review and new formats for science communication are developed and tested in a participatory process with three underserved audiences: Muslim youths with a migration background, socially disadvantaged people in marginalized neighborhoods and students in vocational school. The project "Science for All" is conducted jointly by the Karlsruhe Institute of Technology (KIT) and "Wissenschaft im Dialog" (Science in Dialogue) and funded by the Robert Bosch Stiftung.
} 
primarily theoretical works, are not considered. In order to keep the review focused, guidelines beyond the realm of external science communication (i.e., science communication with a lay public, primarily through science organizations), such as science education for school children or communication in the cultural sector, were not considered in detail, too. These areas might be similar to external science communication and likely also have to address the same problems of exclusion, but there are nevertheless differences in the details and contexts posing inevitably the question of transferability.

Although the topic itself implies a large heterogeneity, an additional focus lies on an overarching perspective. Research with narrow applicability or individual case-studies for selected marginalized groups or single formats (for example science festivals or science slams, are not considered). The same applies to general science communication guidelines, which do not explicitly address reaching underserved or marginalized audiences.

In total, five publications meeting these criteria have been selected as most relevant and are examined further in the following. It is worth noting that two of the reports originate in Austria and two in the United Kingdom. No comparable publications could be found for other European countries, although there might be similar activities, probably not being as easily accessible.

\section{Analyzed Reports and Studies}

In 2010, the Science Center Network delivered a report to the Austrian Council for Research and Technology Development on "Basic characteristics and principles for the dialogue between science and society." "The focus thereby lies on so-called lowthreshold dialogue formats, which are characterized by '(...) the degree of inclusion, openness for different target groups and age groups as well as through the property (...) that access to the topic is possible independent of the state of previous knowledge but at the same time all target groups are being challenged." (Gruber et al., 2010, p. 2). In the report, "lowthreshold" is characterized as participation in an activity with as little effort and as few barriers as possible for participants (Gruber et al., 2010, p. 8). In the conclusion, various principles for a successful dialogue between science and society are presented. The recommendations on "deliberately overcoming social barriers” are (Gruber et al., 2010, p. 58):

- Offering (carefully selected) scientific input

The input has to be accessible from the level of knowledge of the participants and gives them the tools to bring forward their arguments.

- Creating links

This is done by creating connections between the topic and its relevance for the participants (for example through references to their everyday life).

- Addressing different types of learners Based on learning theories different types of learners shall be addressed by using a variety of methods.

- Using an informal setting in small groups

In order to create a better atmosphere for discussions and mitigate participants' fears, small groups should be used.
- Using interactive gamification approaches

When using interactive gamification then information and input should not be forgotten.

- Visiting "everyday spaces"

Certain locations might invoke barriers; thus, one should use spaces familiar to the participants, (for example cafés or libraries).

- Audience led projects

Organizers and institutions should commit to cooperation. This means amongst other things that recommendations of the addressed groups should be considered or the own team is diverse.

Especially the idea of visiting "everyday spaces" has been followed up on through the Science Center Network Vienna with the practical project "knowledge rooms-science communication in local, welcoming spaces to foster social inclusion" (Streicher et al., 2014).

In the 2012 report for the Wellcome Trust "Review of Informal Science Learning" in the United Kingdom, the authors suggest five recommendations for engaging "challenging audience groups" (Lloyd et al., 2012, p. 5) based on a review of activities in the informal science learning sector:

- “making experiences and content relevant to audiences' interests, experiences, and backgrounds, increasing the likelihood of both initial and subsequent engagement and the development of ongoing relationships

- conducting preliminary research with difficult-to-reach audiences, to ensure the accurate tailoring of services and to identify and negotiate social and cultural barriers

- establishing partnerships with other organizations or groups already engaging with the target audience, to help understand audience needs and actual and potential barriers, and to act as trusted conduits between the provider and the audience

- using community outreach methods to engage with target audiences-which, although resource intensive, can lead to embedding an organization within its community

- ensuring experiences are stimulating, interactive and engaging for participants (particularly for young audiences), to stimulate initial engagement more broadly."

Furthermore, they concluded that "practice suggested that sustained engagement requires a strategic approach, working with challenging audiences through a range of activities over a sustained period of time" (Lloyd et al., 2012, p. 5).

As a follow-up, in 2014 the Wellcome Trust commissioned further research on reaching young people from lower socioeconomic groups, consisting of a literature review (Atkinson and Mason, 2014) and new research on the activities and interests of this population (Atkinson et al., 2014b). The results of this research are drawn together in a practical summary report. Key components are "10 steps to successful engagement" (Atkinson et al., 2014a, p. 5,6):

- "Know your objectives and audience:" Both what should be achieved and who is to be reached needs to be known beforehand to adapt the engagement strategies. 
- "Engage a champion and be mindful of family influence:" Persons trusted by the audience can be effective multipliers where traditional authorities, like teachers, might be distrusted. Such multipliers could be coaches or youth workers. Additionally, the influences of the participants' social surroundings need to be considered.

- "Ensure the activity is young person-led:" Young persons and people who are in touch with them-e.g., teachers or peersshould be consulted from the very beginning and be involved in decision making.

- "Ensure the activity is relevant and pitched at the right level:" The activities should be linked to the interests of the intended audience and take their level of knowledge and skills into consideration.

- "Invest in long-term relationships for maximum impact:" Consistent engagement, which takes place on a regular basis, is key to build long-term relationships with young audiences and thus increase impact. Furthermore, the collaboration between institutions working with young people needs to be expanded.

- "Make it practical and interactive:" Hands-on experiences might resonate better with young people than non-interactive activities.

- "Facilitate socializing with friends:" Locations should allow young people to be with their friends.

- "Be financially and geographically accessible:" Trip costs, especially for young people from lower socio-economic backgrounds, can be hard to afford. Thus, locations should be easily accessible for the audience and provide a safe environment.

- "Celebrate and reward successes:" Activities should be (intrinsically) rewarding for the participants to increase their motivation and self-esteem.

- "Communicate carefully and through trusted channels:" The framing of activities, as well as the used communication channels, can influence what the intended audience thinks of them and the willingness to take part.

With the focus of the report, some aspects of the recommendations are youth-specific, at least to the degree of the influence (e.g., family influence), but most equally apply to other underserved or disengaged audiences.

Also, focusing on marginalized children and youth, Marschalek and Schrammel (2017) compiled another report titled "Social inclusion through and within science communication" for the Austrian Council for Research and Technology Development. Therein, they propose 10 guiding principles based on a literature review and qualitative data from workshops and interviews (Marschalek and Schrammel, 2017, p. 22-36):

- Location: Accessible locations should be close to people and have a welcoming design.

- Diversity: To reach a diverse audience it has to be actively invited (for example by respecting their interests and possibilities).

- Evaluation and self-reflection: Constantly evaluating and self-reflecting the inclusiveness within activities is needed.
- Translation and Imparting: Mediators and trusted relationships with the audience as well as a dialogue on par can lead to more inclusion.

- Relevance for daily life: Topics should be chosen according to the audiences' interests, experiences, and knowledge.

- Meaningful moments: Long-lasting activities with enjoyable experiences can create interest and motivation for further engagement.

- Informal learning spaces for science: These spaces should be in the accustomed environment of the audience and respect their mobility and different learning approaches.

- Empowerment: Empowerment might be more important than knowledge transfer.

- Cooperation and Sustainability: Cooperate with institutions already in contact with the intended audience can enhance the quality and sustainability of activities. Such institutions could be libraries, culture clubs, or schools.

- Society and Politics: In order to counter marginalization and exclusion from science communication, it is important to address structural problems and raise awareness of them.

The conclusion of the report includes a series of heterogeneous recommendations, which contain some of the aspects elaborated on before in the report. One repeating aspect is the resemblance to principles of classical community work, similar to the aspects described for the aforementioned concept of the "knowledge ${ }^{\circ}$ rooms" also in Austria.

The last included publication is the dissertation of VásquezGuevara (2019), which has its focus on the United States and Ecuador. The author gives several recommendations for science communication "in culturally diverse scenarios in the Americas" (Vásquez-Guevara, 2019, p. 215-220):

- "Building trust and creating safe spaces and experiences for audience engagement"

Science communication initiatives "first need to build trust with their audiences" (Vásquez-Guevara, 2019, p. 216). This should be done by involving scientists, who listen and collaborate with the audience, by creating safe spaces "that are comfortable and accessible" (Vásquez-Guevara, 2019, p. 217). Events should combine dialogue and participation with technological tools and platforms, like social media.

- "Designing the scientific content framing"

Science communication should frame their messages in a way that resonates with the audiences' habits and lifestyle (for example by offering solutions to real-life problems or in terms of the used language).

- "Opinion leaders for science communication"

Trusted and influential persons within the community such as NGOs, religious leaders or politicians, could connect with the audiences and their circumstances in order to boost engagement with science communication programs.

\section{Comparison and Categorization}

Overall, the five publications show many similarities in the provided recommendations, with differences primarily in the framing and structuring of the guidelines (see Table 1): 
TABLE 1 | Comparison of the recommendations put forward in this paper and those identified in the review.

\begin{tabular}{|c|c|c|c|c|c|}
\hline Recommendation: & Gruber et al. (2010) & Lloyd et al. (2012) & Atkinson et al. (2014a) & $\begin{array}{l}\text { Marschalek and } \\
\text { Schrammel (2017) }\end{array}$ & Vásquez-Guevara (2019) \\
\hline \multirow[t]{2}{*}{ 1) Start with listening } & & $\begin{array}{l}\text { Conducting preliminary } \\
\text { research }\end{array}$ & $\begin{array}{l}\text { Know your objectives and } \\
\text { audience }\end{array}$ & Diversity (actively invited) & \\
\hline & & & & $\begin{array}{l}\text { Evaluation and } \\
\text { self-reflection }\end{array}$ & \\
\hline $\begin{array}{l}\text { 2) Reduce the } \\
\text { distance and be } \\
\text { accessible }\end{array}$ & $\begin{array}{l}{ }^{*} \text { Addressing different } \\
\text { types of learners }\end{array}$ & $\begin{array}{l}\text { Ensuring experiences are } \\
\text { stimulating, interactive and } \\
\text { engaging }\end{array}$ & $\begin{array}{l}{ }^{\star} \text { Ensure the activity is } \\
\text { relevant and pitched at the } \\
\text { right level }\end{array}$ & & $\begin{array}{l}\text { Designing the scientific } \\
\text { content framing }\end{array}$ \\
\hline $\begin{array}{l}\text { 3) Be relevant for } \\
\text { everyday life }\end{array}$ & & $\begin{array}{l}\text { Making experiences and } \\
\text { content relevant to } \\
\text { audiences }\end{array}$ & $\begin{array}{l}\text { Make it practical and } \\
\text { interactive }\end{array}$ & Relevance for daily life & \\
\hline \multirow[t]{2}{*}{$\begin{array}{l}\text { 4) Go where people } \\
\text { are }\end{array}$} & $\begin{array}{l}\text { Visiting "everyday } \\
\text { spaces" }\end{array}$ & $\begin{array}{l}\text { Using community outreach } \\
\text { methods }\end{array}$ & $\begin{array}{l}\text { Facilitate socializing with } \\
\text { friends }\end{array}$ & $\begin{array}{l}\text { Informal learning spaces for } \\
\text { science }\end{array}$ & $\begin{array}{l}\text { Building trust and creating } \\
\text { safe spaces }\end{array}$ \\
\hline & & & $\begin{array}{l}\text { Be financially and } \\
\text { geographically accessible }\end{array}$ & $\begin{array}{l}\text { Accessible locations, close } \\
\text { to people }\end{array}$ & \\
\hline \multirow[t]{2}{*}{ 5) Cooperation is key } & Creating links & $\begin{array}{l}\text { Establishing partnerships } \\
\text { with other organizations or } \\
\text { groups }\end{array}$ & $\begin{array}{l}\text { Communicate through } \\
\text { trusted channels }\end{array}$ & $\begin{array}{l}\text { Cooperation and } \\
\text { Sustainability }\end{array}$ & $\begin{array}{l}\text { Opinion leaders for science } \\
\text { communication }\end{array}$ \\
\hline & Audience led projects & & $\begin{array}{l}\text { Engage a champion and be } \\
\text { mindful of family influence }\end{array}$ & $\begin{array}{l}\text { Translation and Imparting: } \\
\text { Mediators and trusted } \\
\text { relationships }\end{array}$ & \\
\hline $\begin{array}{l}\text { 6) Mind the } \\
\text { "openness paradox" }\end{array}$ & Offering scientific input & & ** & & \\
\hline $\begin{array}{l}\text { 7) Implement } \\
\text { long-term activities }\end{array}$ & & & $\begin{array}{l}\text { Invest in long-term } \\
\text { relationships }\end{array}$ & $\begin{array}{l}\text { Meaningful moments, } \\
\text { Long-lasting activities }\end{array}$ & \\
\hline \multirow[t]{2}{*}{ Not matched } & $\begin{array}{l}\text { (Informal setting in small } \\
\text { groups) }\end{array}$ & & (Reward successes) & Empowerment & \\
\hline & $\begin{array}{l}\text { (Interactive gamification } \\
\text { approaches) }\end{array}$ & & (Activity young person-led) & $\begin{array}{l}\text { Society and Politics: } \\
\text { address structural problems }\end{array}$ & \\
\hline
\end{tabular}

The mapping includes some overlap, since many recommendations include more than one aspect. In the most relevant cases, this is marked with stars in the table. Recommendations in parentheses at the end of the table are addressing only one specific detail and are not matched to the overarching recommendations.

- Two areas are addressed in all five recommendations: first, the importance of actively approaching underserved communities also in a geographical sense to lower barriers by choosing event locations within the communities, that are part of everyday lives instead of trying to invite underserved communities to unfamiliar academic spaces. And second, the importance to work together with communities and partner with familiar organizations and trusted actors to start building trust and a communication relationship oneself.

- Three other aspects are explicitly mentioned only in some of the guidelines, although they are partially or implicitly mentioned within other recommendations respectively: building knowledge on the audience and reflecting your activities, creating accessible and engaging activities, and the importance of making connections to everyday life.

- Two more areas with a wider relevance are only included in one or two publications: First, the importance of long-term engagement, and second the aim to achieve a more basic impact by focusing on empowerment and structural problems.

- Some recommendations, despite still being relevant for successful work in the respective contexts, are not fitting into wider areas and focus operational aspects (e.g., rewarding successes) or are only focused on specific groups or approaches (e.g., gamification approaches or young person led activities).

Although not examined further in-depth here, a comparison with recommendations for reaching underserved audiences in other fields [for example in public administration (Froonjian and Garnett, 2013), adult education (Bremer and Kleemann-Göhring, 2011), or public health (Soom Ammann and Salis Gross, 2011) confirms the underlying core aspects].

\section{Corroborating Qualitative Data}

To deepen the understanding of the exclusion processes and the proposed solutions, we corroborated the results of the review with qualitative data collected in our research. These data stem from the project "Science for All" ["Wissenschaft für alle"] in which science communication formats with underserved audiences are developed and evaluated. To that end, a typology of exclusion factors has been developed based on a literature review (Schrögel et al., 2018) and new formats for science 
communication are developed and tested in a participatory process with three underserved audiences: Muslim youths with a migration background, socially disadvantaged people in marginalized neighborhoods, and students in a vocational school.

\section{Interviews With Practitioners and Researchers}

On the one hand, the data consist of interviews with science communication experts from Germany, Switzerland and Austria working with not reached groups. The interviews were conducted in the first quarter of 2018. A total number of 11 scientific and practitioner experts have been interviewed in a semi-structured phone-interview ${ }^{2}$. The interview partners were chosen because they work with underserved audiences either as practitioners or researchers, come from different fields representing different institutions-e.g., museums, political education, science communication. The selection does not claim to be representative for the international expert landscape. The group consisted of six women and five men all of which have an academic background. Although no further data on socioeconomic status and other demographics have been formally collected, it has to be critically reflected, that the background of the group itself probably represents the prevailing limited diversity within academia.

\section{Focus Groups and Interviews With Underserved Audiences}

On the other hand, focus groups and interviews with three exemplary underserved groups were conducted. The groups were chosen by an advisory board as exemplary case studies of underserved audiences in science communication. The three groups are each characterized by one of the identified exclusion factors, however, it is important to note that they are a statistical group of people with one common attribute, rather than a social group (Vester, 2009, p. 80-81) with a self-identification as a group.

\section{Students in vocational training}

They are usually not considered as target groups for science communication, as they are neither addressed by science communication focusing on recruiting future university students nor are they addressed by typical science communication formats for adults. The specific project partner was a vocational school for plumbing and heating in the city of Karlsruhe, Germany. Two focus groups were conducted in September and November 2018. The first consisted of teachers (2), committed students (7) and a scientist researching political participation of vocational students. The second focus group consisted of seventeen students from one class.

2. Socially disadvantaged people in marginalized neighborhoods Socio-economically disadvantaged and marginalized urban communities are often concentrated in specific city quarters (Otto et al., 2006), which statistically have an above-average unemployment rate, lower formal educational backgrounds, and less scientific, educational, and cultural infrastructure.

\footnotetext{
${ }^{2} \mathrm{~A}$ detailed list of the interviewed experts is provided in the
} Supplementary Material (Table 1).
In this situation, only limited direct contact to science (communication) is available besides mass media channels. Our project partner was the urban development area Falkenhagener Feld East and West in Berlin-Spandau, where the percentage of residents receiving transfer income, the unemployment rate as well as the percentage of children in poverty is well-above the average for Berlin (GeSop mbH, 2019a,b). We conducted one focus group with five engaged persons ${ }^{3}$ in July 2018 and guided interviews with 18 residents over the following months.

3. Muslim youths with a migration background

Especially for Muslims in current Europe, religious affiliation (or even just the externally assumed religious affiliation) can be a target for discrimination against. The religious beliefs often do not even play an actual role, but are a proxy and discrimination is targeting actual or perceived migration backgrounds (European Union, 2017). Such experiences of discrimination are also relevant for the field of science communication, as shown in a UK study (Dawson, 2019). But also for Germany, this discrimination has been reported for young Muslim persons independently of their cultural or family background (El-Mafaalani and Toprak, 2011). Furthermore, religious beliefs indeed also can influence actual or perceived attitudes toward science and science communication (Hagay et al., 2013). For this part, we organized two focus groups in cooperation with two Muslim youth organizations in Berlin, both in April 2019, one with 10 and the other with six participants.

The aim of the focus groups and interviews was to learn more about the respective underserved groups: their everyday lives, their interest, and attitudes toward science and science communication, and their (potential lack of) participation as well as discrimination experiences ${ }^{4}$. The qualitative data from the interviews and focus groups are used to illustrate and complement the recommendations derived from the review of guidelines and recommendations.

\section{ACTIONABLE RECOMMENDATIONS}

We synthesized seven actionable recommendations from our review of guidelines and recommendations and the corroborating data, which play an important role in reaching underserved and marginalized communities with science communication.

The recommendations are presented in the following with concrete starting points for science communication practitioners.

\footnotetext{
3"Engaged persons" (more specifically: socially engaged persons, e.g., community representatives, social workers, teachers, and stakeholders) play important roles in their communities. They were included to gain better access to the communities and to provide a broader experience and an additional reflected perspective, that interviews with individual community members could depict.

${ }^{4} \mathrm{~A}$ detailed list of the conducted interviews and focus groups is provided in the Supplementary Material (Table 2).
} 


\section{Recommendation 1: Start With Listening}

If science communication activities are not to be planned solely based on assumptions and stereotypes, a reflection on one's activities and goals is necessary. Above all, precise analysis and knowledge of the audience reached and not reached so far is required. For this, it is important to listen and ask questions first: How do others perceive science, science communication, or even individual research topics? Which needs do they express? What do they wish for? Even if the answers are not formulated ready for implementation, open discussions can bring many insights. It is important not only to listen but also to respect these wishes. Especially, it is important to respectfully accept a "no" for an answer. It can happen that initially there is no interest in a certain topic within a community, although this might have high relevance for people. For example, if people are facing acute financial challenges, a discussion event on the importance of future technologies in 10 years might be of little direct relevance to them.

Do not expect people to change and become "like you". Rather, "the intention must be to seek out and embrace, on their own terms, the ingenuities that continually arise in the shadows or as subversions of the established narratives" (Coffee, 2008, p. 271; cf. Archer et al., 2016).

This implies that you have to be able to adapt your plans to the needs and wishes of the communities and selfcritically reflect the contents you want to communicate and how they are communicated. This process of (self-) reflection and adaptation should be done regularly throughout the particular project (Aguirre, 2014, p. 11; Marschalek and Schrammel, 2017, p. 25-26).

Letting people talk and actively listening to them can empower them and be a fruitful tool to integrate them without patronizing them. This has been shown for example in the project "Diamond," which used "digital storytelling" in a museum context (Da Milano and Falchetti, 2014). The connection has also been brought up during our interviews. As one expert put it:

\begin{abstract}
"It is about showing people that, with whatever knowledge and know-how, they understand such things. It is about empowerment and arousing interest, about the exchange, but also about the recognition of different positions, and the perception of and listening to different positions." (Expert 10)
\end{abstract}

\section{Recommendation 2: Reduce the Distance and Be Accessible}

The second key point is closely linked to the first. Both in the existing guidelines and our work, there was a consciously or unconsciously perceived distance between communicators and underrepresented groups. One vocational student described this distance as a difference in the social environment:

Student 1: "Most of them come from the Hauptschule or Realschule [secondary school or middle school] and we simply have a completely different environment ${ }^{5}$." ${ }^{5}$ Taken from a focus group with students from the Heinrich-Meidinger-Schule
Karlsruhe (vocational school) on 9/25/2018.
While one participant from the group of young Muslims spoke explicitly of the elitist image of science:

Participant 1: "It is also very often, that is to say, science, as I said earlier that it is very white, I actually associate it directly with exclusion, so it is something very elitist ${ }^{6}$."

This distance can be expressed on many levels: be it as an academic or upper-class language with respect to vocabulary, idioms, or references, a condescending and instructive attitude, or the display of and insisting on academic titles-in short, a certain habitus (Bourdieu, 1982). Since this distance is often the result of one's own-especially socioeconomic-living conditions and the educational system, it will not be possible for a science communication project to overcome it easily. But there are strategies to at least narrow the gap.

For example, you could formulate language in a casual, humorous, and colloquial way. However, at the same time you have to remain authentic and not play an artificial role-that's the challenge as one of the interviewed experts said:

"I need to understand the language, the code. I have to reduce my scientific results without telling scientifically wrong things." (Expert 11)

The use of humor can be a helpful method of making science accessible. This was explicitly recommended in one of our focus groups as one of the central points for reaching them with science communication:

Student 1: "One could make jokes to get closer to people and not to make oneself as important and to behave like the person next to you so that they take you seriously ${ }^{7}$."

It is also important to consider the time and financial resources of the target group, which are sometimes-e.g., for shift workersquite different from those in the academic milieu.

The dialogue should take place at eye level. Our experience shows that (scientific) expertise is respected-titles and references to organizations alone not necessarily:

Participant 1: "Well, I mean, the children and teenagers, so if they have a person who knows what he or she's talking about and can also convey things in an interesting way, then that's respected and recognized, and that's not through a title, expert XY, but through an emotional approach. So the person is measured by what he or she says. And if an expert really conveys things in a substantiated way and is also able to adapt the language ${ }^{8}$."

Initially, the aim should be to sound out emotions, attitudes, and values to create a common basis on which further discussion and knowledge transfer are possible. Current socio-psychological studies on values and emotions in science show that certain attitudes are driven by values and emotions to such an extent

\footnotetext{
${ }^{6}$ Taken from a focus group with young Muslims in Berlin on 4/27/2019.

${ }^{7}$ Taken from a focus group with students from the Heinrich-Meidinger-Schule Karlsruhe (vocational school) on 9/25/2018.

${ }^{8}$ Taken from a focus group with engaged persons in Berlin-Spandau on 7/26/2018
} 
that one cannot achieve anything with information events alone. Dan Kahan, for example, described this observation, which is discussed under the heading "Cultural Cognition" (Kahan et al., 2010b), for information on vaccination (Kahan et al., 2010a).

To this end, it is "necessary to honestly question one's own goals and how they could be achieved" (Marschalek and Schrammel, 2017, p. 26) in advance. How should results be dealt with? Is there even a need for concrete results or a comprehensive transfer of knowledge, or is the exchange itself a goal?

It is advisable to take an open approach: This means making an offer and moderating debates without having a too narrow idea of what should ultimately happen in the minds of the participants. However, it should be taken into account that too much vagueness can also hinder communication (see recommendation 6).

\section{Recommendation 3: Be Relevant for Everyday Life}

\begin{abstract}
Student 1: "The [scientific] topics are simply too far away for us ${ }^{9}$." Student 6: "We're just craftsmen, we need to see what we are doing. Just listening to a lecture-many just don't understand it. [...] Bringing theory to practice $[\ldots]^{9 "}$
\end{abstract}

We often encountered statements such as these in our conversations with people in a marginalized part of the city and with vocational school students. Science in general and thus also science communication seemed to them to be remote from their everyday life, inaccessible, complicated and correspondingly uninteresting.

For this reason, concrete topics or hooks that tie in with already existing interests or life situations contribute decisively to the success of science communication. In vocational schools, this can include, for example, job-related technical interests:

\begin{abstract}
Moderator: "Are there any other scientific topics that you are particularly interested in?"

Student 6: "Yes, I'm interested in renewable energies. This is also part of our profession. You should know something about that."
\end{abstract}

Establishing these links "between their homes, personal lives, communities, and science are important" (Archer et al., 2016, p. 936), as experiences from other projects show, too. For example, Marschalek and Schrammel (2017, p.28), state that in their project "exhibition objects or exhibition themes with a relation to the everyday life of the target group, create particular interest and encourage coming back" (cf. Streicher et al., 2014). The same holds for connections to the cultural background and other experiences of the underserved audiences (Archer et al., 2016, p. 936).

The relevance of topics cannot be measured solely by whether they relate to everyday life in terms of content. Starting points can also be found in more pragmatic aspects not related to the topic, for example in a scientific holiday program for children, ${ }^{9}$ Taken from a focus group with students from the Heinrich-Meidinger-Schule
Karlsruhe (vocational school) at 9/25/2018. which offers free care as a benefit ${ }^{10}$, or in an entertaining scientific event that offers an interesting leisure activity away from daily struggles.

In many cases we have noticed that science hardly plays a role outside very concrete benefit considerations-for example, to support career plans or as education for their children:

Interviewee 7: "I want my kids to learn how to do research and have fun with it $[\text { science }]^{11}$."

This is usually not a rejection, but a low priority compared to other topics (see recommendation 1), as the following quote from one of our interviews in Berlin-Spandau illustrates:

Interviewer: "Is it right then to say that for you other things are more important that have to be changed before you get to grips with science?"

Interviewee 8: "Yes, exactly. If other things were settled, then my interest would increase ${ }^{12}$."

\section{Recommendation 4: Go Where People Are}

If you want to address groups that have not been reached so far, it is helpful to also approach these groups quite literally in a spatial sense. You should use places and buildings that are familiar, easily reachable and accessible for the group- "localities in the everyday environment of the people" (Marschalek and Schrammel, 2017, p. 22), because "socially inclusive science communication has to take place where people spend most of their time-within their communities" (Streicher et al., 2014, p. 1). This holds true for science communication as well as for other areas of community building and engagement. In our focus groups, a vocational student explicitly expressed this demand:

Student 4: "If you-in the job, for example-have a lot of school during the apprenticeship, then rather the people from universities should simply come to the school, give lectures ${ }^{13}$."

In concrete terms, this means organizing events in the district center, the village pub, or vocational school instead of the university or research institute-which often are perceived as closed-off areas. For example, Streicher et al. (2014) used empty salerooms in socially disadvantaged areas of Vienna to open up so-called "knowledge rooms."

This approach has also been echoed by one of the interviewed experts, who stated in an interview, that

"you always have to go into the neighborhood and sometimes you also have to invite people first. Or another experience we had with refugees, you have to go there and sometimes you have to accompany the people to bring them to the museum." (Expert 4)

\footnotetext{
${ }^{10}$ In Switzerland, for example, this is the concept of the so-called Camp Discovery, which addresses children with little contact to science and from low-income families (Science et Cité, 2010).

${ }^{11}$ Taken from a guided interview with a resident in Berlin-Spandau on 9/8/2019.

${ }^{12}$ Taken from a guided interview with a resident in Berlin-Spandau on 9/8/2019.

${ }^{13}$ Taken from a focus group with students from the Heinrich-Meidinger-Schule Karlsruhe (vocational school) on 9/25/2018.
} 
In addition to closeness and physical accessibility, (for example for people in wheelchairs, other exclusion mechanisms can also play a role). There are places some people just won't go because they feel that these places are "not for them" (Dawson, 2019, p. 100-102). Specifically for science communication, both a fenced research center with guards and admission controls and a classicist science building (which already seems to signal on the façade that you can't get very far here without being able to have fluent conversations in Latin) for example do not appear welcoming to many people (Marschalek and Schrammel, 2017, p. 22). Thus, it seems important to mind easy accessibility and reachability of the location, as well as a familiar and open atmosphere, a direct dialogue with the community and multilingual information and offerings (Archer et al., 2016, p. 936; Streicher et al., 2014).

This so-called outreach approach can also mean connecting to existing events with a communication format, for example being represented with a booth at a block party or giving a lecture at an event of a local initiative or an association.

\section{Recommendation 5: Cooperation Is Key}

Wherever possible, cooperation with local stakeholders, and engaged persons is recommended. They can be found in neighborhood management, social work, libraries, associations, schools, educational initiatives, and self-help groups-or in committed members of the target group itself (Lloyd et al., 2012, p. 55; Marschalek and Schrammel, 2017, p. 34; Smithsonian Institution Office of Policy Analysis, 2001, p. vi-vii).

They know the situation and the needs of the people and thus make insights and approaches possible in the first place. They can advise on the relevance of topics, working approaches, and avoidable pitfalls. Often, they are trusted persons for the community and their word carries weight in the group. This turns them into door openers building up trust, which is often a prerequisite to successful communication projects (Marschalek and Schrammel, 2017, p. 27, 35).

This is also true for communicating via mass media, as the following statement from one expert illustrates:

\footnotetext{
"This goes through emotionalization, it is identification with the peer, because we just do peer-to-peer communication. This means that they are peers or only slightly older influencers who have a similar life reality, who know the needs, wishes, and topics of their community on the channel and with whom we clearly talk about what are the approaches to this topic. How does it affect you?" (Expert 1)
}

Another possibility is that researchers with connections to the target group play an important role in a communication project. This could be scientists who live in a neighborhood or region, have the same cultural background or come from a non-academic home. Based on their own experience, they can advise on the preparation and planning of communication projects and participate as credible and authentic speakers in their implementation.

Furthermore, in the existing guidelines as well as in our work it turned out that potential cooperation partners have only very limited time and financial resources (Marschalek and Schrammel, 2017 , p. 34). They understandably want to focus these few resources on their respective core tasks. Even if the requested contribution is "only" limited to counseling and facilitating access to the community, it is another project that requires at least some coordination and attention.

It is therefore crucial that potential cooperation partners are not simply regarded as service providers. Their interests and their limited time should be respected and the extent to which they can benefit from cooperation in the short and long term should be taken into account:

"You also have to look, what is the ultimate benefit for stakeholders when they participate in such programs? So where do you practically take their interests into account?" (Expert 5)

In this context, Dawson (2019, p. 92) describes a striking example of bad cooperation:

\begin{abstract}
"Maria from the Latin American group told me a similar story about how frustrated she had been when her community group were asked by a prestigious London museum to be part of their Day of the Dead celebrations. No language provision was made for her friends who were less fluent in English and community artists (dancers and musicians) were expected to perform for free, without even their food or travel expenses covered."
\end{abstract}

\section{Recommendation 6: Mind the "Openness Paradox"}

The "Science for All" project started with a very open and participatory approach: Following an engagement paradigm and understanding science communication as dialogue, we wanted the participating groups to be able to make independent decisions on the kind of science communication format, its contents and its implementation.

However, that openness made it harder for us and the participants at first, even if this sounds paradoxical. The more open the project, the more prior knowledge, and initiative the participants need. The joint development of the topic and format was difficult to communicate, whether to potential project partners or the groups themselves. This challenge is not only based on specific knowledge gaps, but maybe even more so on differences in cultural and science capital. Participatory formats are much more inviting and accessible for communities that have experienced self-efficacy in shaping their careers and being part of a political and scientific discourse.

With a concrete institution as a sender (such as a university or an association in a district), a goal defined by it (e.g., a topicspecific educational mission) and a topic set by it (which derives from the work of the institution, e.g., basic scientific education), the prerequisites would probably be more favorable.

This is true for interaction, too. Interaction is often praised as a tool for making science communication more attractive (e.g., The Science Museum, 2016; Sievert and Purav, 2018), but interaction also requires an understanding of how it works and how to make the best use of it on the participants' side. This makes it less 
accessible especially for people with low literacy (Dawson, 2019, p. 114).

However, this does not mean the first advice-listening-is superfluous. You should still be open to the needs and interests of the people and adapt accordingly, but at the same time not ask too much of them.

\section{Recommendation 7: Implement Long-Term Activities}

Project financing is often limited to one-off activities and pilot projects, especially driven by an increasing short-term and only project-based funding in science instead of a basic financing of independent scientific institutions. If these projects are designed accordingly, these can indeed develop an experiential character, attract attention, and create a first approach. However, if it stops there, the effect will quickly fizzle out and lead to frustration among the groups addressed. This even applies if local intermediaries support the project. It might still not be perceived as an authentic initiative from within the community and with a long-term perspective and lasting impact. In the end, it can be very time-consuming to build the trust between the science institutions and communicators and the people addressed, which is often a prerequisite to reach them (see recommendation 5).

While this recommendation would apply to many other forms of communication, it is particularly relevant for engaging underserved communities with a history of being marginalized. Dawson (2019, p. 92) shows how one-time activities-even when they are well-intentioned-can backfire by describing that one of her interview partners "argued everyday science learning activities tailored to her community during Black history month were tokenistic, angrily stating, 'we're not invited the rest of the year!"

It would be ideal if an institution or initiative with a concrete local reference (such as the district or the environment of a university) or group-specific contacts (self-help group, community association) started a project, instead of an intervention from the outside. This should also have at least a medium-term perspective so that the start-up phase necessary in all projects can then be used to generate further interest and participation.

\section{DISCUSSION AND CONCLUSION}

The structuring of the recommendations is aimed at being broadly applicable across different contexts and projects. The wording was chosen to be less technical and instead memorable to aid the dissemination and take-up of the recommendations by science communication practitioners and the leadership at science institutions.

The synthesized seven recommendations are arranged in a project logic ("Starting with listening" at the beginning, "Implementing-long-term activities" as perspective at the end). They include six of the common areas identified in the review (see section comparison and categorization and also Table 1): Starting with listening (1), reducing the distance (2), relevance for everyday life (3), going where people are (4), cooperation (5), and implementing long-term activities (7). Theses aspects were not only presented in the literature but were also corroborated by expert statements and most importantly voiced by members of the three underserved audiences themselves which were interviewed within our project.

The seventh recommendation "minding the 'openness paradox"' (6) was no major part in the reviewed guidelines and only mentioned indirectly. However, we consider this an important aspect that needs special attention. The ideal of modern science communication has shifted from an outdated "deficit model" (which nevertheless still is prevalent in many institutions and approaches) toward a model of dialogue and participation. But while we welcome this shift, it might create new barriers and exclusion by requiring skills and knowledge as well as cultural and science capital to join an interactive exchange with science. This needs to be addressed in the design and implementation of participatory science communication.

Besides the more project-specific and operational recommendations being left out in the synthesis of the seven recommendations presented here, it is worth noting that one of the wider areas identified in the review, empowerment, and structural problems, is not considered explicitly. While this is probably one of the most important overall aspects to promote inclusion and an equitable society, it rather represents a mindset and a long-term strategic goal than an actionable recommendation that can be addressed within one project. These issues need to be tackled on a societal level and require systemic changes (cf. Birmingham, 2016; Marschalek and Schrammel, 2017, p. 35-37; Dawson, 2019). For example, in our focus groups with young Muslims, participants complained about discrimination in the educational system:

Participant 7: "What I thought was really bold was that in the 10th grade we got a vocational counseling to which somehow everyone had to go once, and everyone was recommended to do an apprenticeship and not to continue the Abitur [universityentrance diploma]. That is so bold and cheeky simply, where I think, so I go ... Before she asks me what I want to do at all, she says, yes, I would definitely recommend you this and that, this apprenticeship. Where I think, so hey, I want to do Abitur and so on ${ }^{14}$."

Participant 1: "My teacher's reason was also that my parents come from a working-class and are construction workers and I should also go in this direction and not study, which means that you are very quickly excluded before you have even spoken the word science ${ }^{15}$."

Indeed, the proposed guidelines can be understood as a "weak form of inclusion" (Dawson, 2019, p. 137), only addressing a limited set of the intersecting exclusion factors present in the field of science communication (Schrögel et al., 2018). Thus, one should always consider what exactly has prevented people so far to take part in science communication activities-and how these exclusion factors might intersect. For example, Dawson (2019) describes that people working in precarious jobs not only have a

\footnotetext{
${ }^{14}$ Taken from a focus group with young Muslims in Berlin at 4/9/2019.

${ }^{15}$ Taken from a focus group with young Muslims in Berlin at 4/27/2019.
} 
low income but also at the same time often have little free time at their disposal. Thus, scraping the entrance fee for museums in the UK addressed the low income, still left the time issues unsolved, so that in the end "getting rid of upfront entrance costs did little to change the visitor profile to these museums" (Dawson, 2019, p. 95).

Nevertheless, we think the recommendations might be useful for projects with limited scope and resources-both regarding time and finances-in broadening "access and accessibility" (Birmingham, 2016, p. 955) and as a starting point for more fundamental changes. Inclusion of broad segments of society into science communication and the discourse about science is highly relevant, considering that being included is an important prerequisite for participation in modern society [for example as a support for evidence-based individual decisions (The Royal Society, 1985 , p. 10), for personal career development (Blanton and Ikizer, 2019, p. 155), or the informed participation in democratic processes and public debates (Thomas and Durant, 1987, p. 5)].

It has to be acknowledged that the proposed guidelines as well as the reviewed material have a strong European or Western focus. This choice has been made deliberately to raise awareness and drive change in science communication in this domain. However, it is important to also keep global perspectives and global engagement with science in mind, especially considering the global impact of science and the need for science-based solutions to global challenges. Furthermore, the guidelines presented here are not absolute truths. Their usefulness and practical implementation depend on the concrete circumstances in which the communication of science takes place. There might be further useful recommendations missing here, too.

Additionally, taking part in inclusion or diversity training can sensitize for and deepen the understanding of exclusion mechanisms and how to tackle them (Archer et al., 2016, p. 936; Marschalek and Schrammel, 2017 , p. 28) and create the essential awareness for inclusion:

"What we have noticed time and again, however, is that already on the organizers' side there must be a certain awareness of the need to reach such target groups at all. So if they have no idea at all how diverse their potential target group is, then it is also difficult

\section{REFERENCES}

Aguirre, C. (2014). Science Centers. Which Role can They Play to Participate in a City Social Reconstruction? JCOM 13, 1-12. Available online at: https:// jcom.sissa.it/archive/13/02/JCOM_1302_2014_C01/JCOM_1302_2014_C04 (accessed December 16, 2017).

Allen-Ramdial, S.-A. A., and Campbell, A. G. (2014). Reimagining the pipeline: advancing stem diversity, persistence, and success. BioScience 64, 612-618. doi: 10.1093/biosci/ biu076

Archer, L., Dawson, E., Seakins, A., and Wong, B. (2016). Disorientating, fun or meaningful? disadvantaged families' experiences of a science museum to set diversity for individual offers or targeted communication measures." (Expert 6)

Science communication for and with underserved audiences is always a balancing act between trying to be as inclusive to as many people as possible and specializing in the needs of certain groups. While most efforts to connect with marginalized communities will make science communication more inclusive for the whole society, undoubtedly some will conversely exclude some other people and therefore require thoughtful decisions and open discussions. Overall, many small steps in changing the common practices of science communication can together create a meaningful impact.

\section{AUTHOR CONTRIBUTIONS}

All authors contributed equally to the data collection and the writing of the paper.

\section{FUNDING}

The research addressed in this paper is part of the project Science for All funded by the Robert Bosch Stiftung.

\section{ACKNOWLEDGMENTS}

We would like to thank the participants in our focus groups as well as our interview partners for their cooperation and for giving consent to the publication of pseudonymized verbatim quotes. We would like to thank the reviewers for their helpful comments and questions that led to a significant improvement of the article. Also, we would like to thank our colleagues from the project Science for All at Wissenschaft im Dialog as well as Annette Leßmöllmann for the fruitful discussions that led to the development of the recommendations. We acknowledge support by the KIT-Publication Fund of the Karlsruhe Institute of Technology.

\section{SUPPLEMENTARY MATERIAL}

The Supplementary Material for this article can be found online at: https://www.frontiersin.org/articles/10.3389/fcomm. 2020.00042/full\#supplementary-material

visit. Cult. Stud. Sci. Educ. 11, 917-939. doi: 10.1007/s11422-015-9 667-7

Atkinson, R., and Mason, C. (2014). Experiments in Engagement: Review of Literature Around Engagement With Young People From Disadvantaged Backgrounds. Available online at: https://wellcomelibrary.org/item/ b21243414\#? $\mathrm{c}=0 \& \mathrm{~m}=0 \& \mathrm{~s}=0 \& \mathrm{cv}=0$ (accessed August 16, 2019).

Atkinson, R., Siddall, K., and Mason, C. (2014a). Experiments in Engagement: Engaging With Young People From Disadvantaged Backgrounds. Available online at: https://wellcomelibrary.org/item/b21243402\#? $\mathrm{c}=0$ \&m $=0 \& \mathrm{~s}=0$ \&cv $=0$ (accessed August 16, 2019).

Atkinson, R., Siddall, K., and Mason, C. (2014b). Experiments in Engagement: Research Into Engagement Activities With Young People From Disadvantaged 
Backgrounds. Available online at: https://wellcomelibrary.org/item/ b21243426\#? $c=0 \& m=0 \& s=0 \& c v=0$ (accessed August 16, 2019).

Birmingham, D. (2016). "Disorienting, fun or meaningful?": looking beyond the boundaries of the museum. Cult. Stud. Sci. Educ. 11, 953-958. doi: $10.1007 / \mathrm{s} 11422-015-9705-5$

Blanton, H., and Ikizer, E. G. (2019). Elegant science narratives and unintended influences: an agenda for the science of science communication: unintended influence. Soc. Issues Policy Rev. 13, 154-181. doi: 10.1111/sipr. 12055

Borgmann, M. (2005). Evaluation Synthesis zu Angeboten der Wissenschaftskommunikation im Rahmen der Evaluation des "Jahrs der Technik 2004" [Evaluation synthesis on science communication offers within the evaluation of the "year of technology 2004"]. Cologne: Univation. 1-128. doi: 10.2314/GBV:506379280

Bourdieu, P. (1982). Die feinen Unterschiede. Kritik der gesellschaftlichen Urteilskraft. 26. Auflage. Frankfurt am Main: Suhrkamp.

Bremer, H., and Kleemann-Göhring, M. (2011). Weiterbildung und "Bildungsferne". Forschungsbefunde, theoretische Einsichten und Möglichkeiten für die Praxis. Duisburg. Available online at: https://www.uni-due.de/imperia/ $\mathrm{md} /$ content/politische-bildung/arbeitshilfe_potenziale (accessed January 18, 2018).

Bultitude, K. (2014). Science festivals: do they succeed in reaching beyond the 'already engaged'? J. Sci. Commun. 13, 1-3. doi: 10.22323/2.13040301

Coffee, K. (2008). Cultural inclusion, exclusion and the formative roles of museums. Mus. Manag. Curatorship. 23, 261-279. doi: 10.1080/09647770802234078

Da Milano, C., and Falchetti, E. (2014). Stories for Museums, Museums for Stories. Digital Storytelling and Inclusive Scientific Museums: a European Project. Nepi: Vetrani Editore srls.

Dawson, E. (2019). Equity, Exclusion \& Everyday Science Learning. The Experiences of Minoritised Groups. Abingdon, Oxon; New York, NY: Routledge.

de Freitas, C., and Martin, G. (2015). Inclusive public participation in health: policy, practice and theoretical contributions to promote the involvement of marginalised groups in healthcare. Soc. Sci. Med. 135, 31-39. doi: 10.1016/j.socscimed.2015. 04.019

El-Mafaalani, A., and Toprak, A. (2011). Muslimische Kinder und Jugendliche in Deutschland: Lebenswelten - Denkmuster - Herausforderungen. Sankt Augustin: Konrad Adenauer Stiftung.

European Union (2017). Second European Union Minorities and Discrimination Survey. Muslims - Selected Findings. Luxembourg: European Union. Available online at: https://fra.europa.eu/sites/default/files/fra_uploads/fra-2017-euminorities-survey-muslims-selected-findings_en.pdf (accessed September 20, 2019).

Froonjian, J., and Garnett, J. L. (2013). Reaching the hard to reach: drawing lessons from research and practice. Int. J. Public Adm. 36, 831-839. doi: $10.1080 / 01900692.2013 .795161$

GeSop mbH (2019a). IHEK 2019-2022. Integriertes Handlungs- und Entwicklungskonzept Quartiersmanagement Falkenhagener Feld Ost BerlinSpandau. Available online at: https://falkenhagener-feld-ost.de/ff-ostwordpress/wp-content/uploads/2019/08/IHEK-FF-Ost-2019-2022-nB.pdf (accessed May 20, 2020).

GeSop mbH (2019b). IHEK 2019-2022. Integriertes Handlungs- und Entwicklungskonzept Quartiersmanagement Falkenhagener Feld West BerlinSpandau. Available online at: https://falkenhagener-feld-west.de/ff3010/wpcontent/uploads/2019/08/IHEK-FF-West2019-2022-nB-2.pdf (accessed May 20, 2020).

Gruber, S., Unterleitner, K., and Streicher, B. (2010). Grundlegende charakteristika und prinzipien für den dialog wissenschaft und gesellschaft. ScienceCenter Netzwerk. Available online at: http://www.rat-fte.at/tl_files/uploads/Studien/ Endbericht_Evaluation_Dialog_FINAL.pdf (accessed November 16, 2017).

Hagay, G., Baram-Tsabari, A., Ametller, J., Cakmakci, G., Lopes, B., Moreira, A., et al. (2013). The generalizability of students' interests in biology across gender, country and religion. Res. Sci. Educ. 43, 895-919. doi: $10.1007 /$ s11165-012-9289-y

Humm, C., Schrögel, P., and Leßmöllmann, A. (2020). Feeling left out: underserved audiences in science communication. Media Commun. 8, 164176. doi: $10.17645 /$ mac.v8i1.2480
Kahan, D. M., Braman, D., Cohen, G. L., Gastil, J., and Slovic, P. (2010a). Who fears the HPV vaccine, who doesn't, and why? an experimental study of the mechanisms of cultural cognition. Law Hum. Behav. 34, 501-516. doi: 10.1007/s10979-009-9201-0

Kahan, D. M., Jenkins-Smith, H., and Braman, D. (2010b). Cultural cognition of scientific consensus. J. Risk Res. 14, 147-174. doi: 10.2139/ssrn.15 49444

Kennedy, E. B., Jensen, E. A., and Verbeke, M. (2017). Preaching to the scientifically converted: evaluating inclusivity in science festival audiences. Int. J. Sci. Educ. B 8, 14-21. doi: 10.1080/21548455.2017.1371356

Kreps, G. L. (2005). Disseminating relevant health information to underserved audiences: implications of the Digital Divide Pilot Projects. J. Med. Libr. Assoc. 93, S68-73.

Leiserowitz, A., Maibach, E., and Roser-Renouf, C. (2009). Global Warming's Six Americas 2009. Yale University. Available online at: https:// climatecommunication.yale.edu/wp-content/uploads/2016/02/2009_05_ Global-Warmings-Six-Americas.pdf (accessed May 20, 2020).

Lloyd, R., Neilson, R., King, S., and Dyball, M. (2012). Review of Informal Science Learning. Available onilne at: https://wellcomelibrary.org/item/b21247213\#?c= $0 \& \mathrm{~m}=0 \& \mathrm{~s}=0 \& \mathrm{cv}=0$ (accessed February 20, 2018).

Marschalek, I., and Schrammel, M. (2017). Soziale Inklusion durch und in Wissenschaftskommunikation. Studie zur Situation von marginalisierten Kindern und Jugendlichen in Wien. Available online at: http://www.rat-fte. at/tl_files/uploads/Studien/Publikationen/INKLUSIO\%20ENDBERICHT_ FINAL.pdf (accessed December 7, 2017).

Niemann, P., Schrögel, P., and Hauser, C. (2017). Präsentationsformen der externen wissenschaftskommunikation: ein vorschlag zur typologisierung. Zeitschrift für Angewandte Linguistik 67, 81-113. doi: 10.1515/zfal-20 17-0019

Office of Science and Technology and Wellcome Trust (2001). Science and the public: a review of science communication and public attitudes toward science in Britain. Public Understand. Sci. 10, 315-330. doi: 10.1088/0963-6625/10/3/305

Otto, H.-U., Ziegler, H., and Landhäußer, S. (2006). "Informelles Lernen in benachteiligten Stadtteilen," in Orte der Bildung im Stadtteil. Dokumentation des Fachforums der Regiestelle EઐC: Orte der Bildung im Stadtteil 16 (Berlin). Available online at: https://pub.uni-bielefeld.de/record/1943203 (accessed September 21, 2019).

Pandya, R. E. (2012). A framework for engaging diverse communities in citizen science in the US. Front. Ecol. Environ. 10, 314-317. doi: 10.1890/12 0007

Schäfer, M. S., Füchslin, T., Metag, J., Kristiansen, S., and Rauchfleisch, A. (2018). The different audiences of science communication: a segmentation analysis of the Swiss population's perceptions of science and their information and media use patterns. Public Understand. Sci. 27:096366251775288. doi: 10.1177/09636625177 52886

Schäfer, M. S., Kristiansen, S., and Bonfadelli, H. (eds.). (2015). "Wissenschaftskommunikation im Wandel: Relevanz, Entwicklung und Herausforderungen des Forschungsfeldes," in Wissenschaftskommunikation im Wandel, Bonfadelli (Köln: Herbert von Halem), 10-42.

Scheufele, D. A. (2018). Beyond the choir? the need to understand multiple publics for science. Environ. Commun. 12:1521543. doi: 10.1080/17524032.2018.1521543

Schrögel, P., Humm, C., Leßmöllmann, A., Kremer, B., Adler, J., and Weißkopf, M. (2018). Nicht erreichte Zielgruppen in der Wissenschaftskommunikation: Literatur-Review zu Exklusionsfaktoren und Analyse von Fallbeispielen. Berlin; Karlsruhe. Available online at: https://nbn-resolving.org/urn:nbn:de:0168ssoar-66846-1 (accessed June 7, 2018).

Schrögel, P., Humm, C., Rauscher, S., and Kremer, B. (2019). Science for all - Interim Report (Executive Summary). Available online at: http://wmk.itz. kit.edu/downloads/Science_for_all_Factsheet_English.pdf (accessed June 19, 2019).

Science et Cité (2010). Camp Discovery. Available online at: https://www.scienceet-cite.ch/de/camp-discovery (accessed July 26, 2019).

Sievert, S., and Purav, P. (2018). Interactive Science Communication. LUCID. Available online at: https://lucid.wisc.edu/interactive-science-communication/ (accessed July 30, 2019). 
Smithsonian Institution Office of Policy and Analysis (2001). Increasing Museum Visitation by Under Represented Audiences. An Exploratory Study of Art Museum Practices. Available online at: https://repository.si.edu/handle/10088/ 26486 (accessed December 6, 2017).

Soom Ammann, E., and Salis Gross, C. (2011). Schwer erreichbare und benachteiligte Zielgruppen. Teilprojekt im Rahmen des Projekts Best Practice Gesundheitsförderung im Alter Zusammenfassung und Empfehlungen. Institut für Sucht- und Gesundheitsforschung. Available online at: https:// gesundheitsfoerderung.ch/assets/public/documents/de/5-grundlagen/ publikationen/gfia/best-practice/Via_-_Best-Practice-Studie_Schwer_ erreichbare_und_benachteiligte_Zielgruppen_Zusammenfassung_und_ Empfehlungen.pdf (accessed March 2, 2018).

Streicher, B., Unterleitner, K., and Schulze, H. (2014). Knowledge rooms - science communication in local, welcoming spaces to foster social inclusion. JCOM 13, C03. Available online at: https://jcom.sissa.it/archive/13/02/JCOM_1302_ 2014_C01/JCOM_1302_2014_C03 (accessed December 16, 2017).

The Royal Society (1985). The Public Understanding of Science. London. Available online at: https://royalsociety.org/ /media/royal_society_content/ policy/publications/1985/10700.pdf (accessed January 24, 2019).

The Science Museum (2016). Science Museum opens spectacular interactive gallery to inspire wonder in a new generation. Science Museum. Available online at: https://www.sciencemuseum.org.uk/about-us/press-office/science-museumopens-spectacular-interactive-gallery-inspire-wonder-new (accessed July 30, 2019).
Thomas, G., and Durant, J. (1987). "Why should we promote the public understanding of science?", in Scientific Literacy Papers, ed M. Shortland (Oxford: Univ. of Oxford Dept. for External Studies), 1-14.

Tsui, L. (2007). Effective strategies to increase diversity in STEM fields: a review of the research literature. J. Negro Educ. 76, 555-581. Available online at: https:// www.jstor.org/stable/40037228 (accessed April 1, 2020).

Vásquez-Guevara, D. H. (2019). Science for all: exploring science Communication for Public engagement in culturally Diverse Scenarios in the Americas [Dissertation, University of New Mexico]. Available online at: https:// digitalrepository.unm.edu/ltam_etds/48/ (accessed May 20, 2020).

Vester, H.-G. (2009). Kompendium der Soziologie I: Grundbegriffe. Wiesbaden: VS Verlag für Sozialwissenschaften.

Conflict of Interest: The authors declare that the research was conducted in the absence of any commercial or financial relationships that could be construed as a potential conflict of interest.

Copyright $\odot 2020$ Humm and Schrögel. This is an open-access article distributed under the terms of the Creative Commons Attribution License (CC BY). The use, distribution or reproduction in other forums is permitted, provided the original author(s) and the copyright owner(s) are credited and that the original publication in this journal is cited, in accordance with accepted academic practice. No use, distribution or reproduction is permitted which does not comply with these terms. 